\title{
Respecting Human Rights in Population Policies: AN INTERnational Customary Right to ReProductive Choice
}

\begin{abstract}
All couples and individuals have the basic right to decide freely and responsibly the number and spacing of their children and to have the information, education and means to do so. ${ }^{1}$
\end{abstract}

At the 1994 International Conference on Population and Development ${ }^{2}$ in Cairo, Egypt, 179 nations joined in consensus ${ }^{3}$ to support the right to reproductive choice. ${ }^{4}$ Within the context of the interdependence of overpopulation, social and economic development, degradation of the environment, and women's rights, the countries attending the 1994 Population Conference issued a report that broadly expanded the meaning of the right to reproductive choice.

This paper posits that a human right to reproductive choice exists under international customary law. This right derives from various international treatises and non-binding resolutions and from the various laws of the nations.

After establishing that a basic international human right to reproductive choice exists, this paper posits that the right necessarily encompasses two primary rights. First, it includes the right to "the information, education and means" to determine the number and spacing of children. Subsumed within this right is the right to information about and access to contraceptives, the right to education, the right to be free from discrimination and violence and the right to reproductive health services. This right does not include the right to abortion.

1. Report of the International Conference on Population and Development, U.N. International Conference on Population and Development, at 15, U.N. Doc. A/CONF.171/13 (1994) [hereinafter 1994 Population Report].

2. Hereinafter 1994 Population Conference.

3. 1994 Population Report, supra note 1, at 120-22.

4. The right to decide the number and spacing of children has been referred to differently by various authors. Berta E. Hernandez, To Bear or Not to Bear: Reproductive Freedom as an International Human Right, 17 BROOK. J. INT'L L. 309 (1991) (referring to this right as the "right to reproductive freedom" and arguing that the right encompasses the international right to abortion); Ivonne Prieto, International Child Health and Women's Reproductive Rights, 14 N.Y.L. SCH. J. INT'L \& COMP. L. 143 (1993) (referring to the right as "individual right to family planning" and implying that the right only encompasses the right to contraceptives); Reed Boland, et al., Honoring Human Rights in Population Policies: From Declaration to Action in PopUlation Polices Reconsidered: Health, EMPOWERMENT, AND Rights 89, 94 (Gita Sen, et al., eds., 1994) [hereinafter Honoring Human Rights] (using the term "reproductive choice" to include more than the right to contraceptives and information about and access to them, but also to include the right to abortion); and STEPHEN L. ISAACS, POPULATION LAW AND POLICY: SOURCE MATERIALS AND ISSUES 352 (1981) (using the term "fertility control"). This author will use the term "right to reproductive choice," because it seems more analogous to her definition of the right than the other terms. This author defines the "right to reproductive choice" to include the right to information about and access to contraceptives and the right to empowerment to effectively exercise this right to contraceptives. The definition of the term does not include the right to abortion. 
Second, the right to reproductive choice includes the right to decide "freely" the number and spacing of children. Subsumed within this right is the right to be free from governmental coercion, including overt coercion as well as incentives and disincentives, when exercising the right to reproductive choice.

This note examines each of these arguments within the context of the overpopulation and environmental degradation debate. Part I surveys both the extent of the population problem and reasons for the attempt to limit population growth. Part II argues that a human right to reproductive choice exists under international customary law. Part III examines the meaning of this right.

\section{The DEBate on OVER-POPUlation aND ENVIRONMENTAL DEGRadation}

\section{A. The Scope of the Population Crisis}

In this century, world population has changed drastically. As recently as 1920 , it was only two billion. ${ }^{5}$ By 1960 , it had grown to three billion. ${ }^{6}$ In 1974, the figure hit four billion, and only thirteen years later, it hit five billion. ${ }^{7}$ Today, the world population is 5.6 billion. ${ }^{8}$ The United Nations estimates that the world population is growing by eighty-six million people per year. ${ }^{9}$

The United Nations' low, medium and high growth variant projections predict that the world population in twenty years could be 7.1 billion, 7.5 billion or 7.8 billion, respectively. The difference of 720 million people exceeds the current population of Africa. ${ }^{10}$

Every hour, the world's population grows by 11,000 people." Every year, the world adds the equivalent of the population of Mexico, and every decade, the world adds 1 billion more people. ${ }^{12}$

To grasp the rate of population growth, consider these analogies:

5. Elizabeth Rohrbough, On Our Way to Ten Billion Human Beings: A Comment on Sustainability and Population, 5 COLO. J. INT'L ENVTL. L. \& POL'Y 235 (1994).

6. Id.

7. Id.

8. 1994 Population Report, supra note 1, at 9; Julia Preston, U.N. Report: To Stem Population, Empower Women Controversial Document Declares Fertility Is the Key to Sustainable Development, WASH. POST, Aug. 18, 1994, at A24.

9. 1994 Population Report, supra note 1, at 9.

10. $\mathrm{Id}$.

11. George D. Moffett, Critical Masses: The Global Population Challenge 12 (1994).

12. Jessica Mathews, The Abortion Distraction: The True Subject at Cairo Is Population -It's a Lot More Urgent Than Some Think, WASH. PoST, Sept. 12, 1994, at A23. The author of this editorial piece is a senior fellow at the Council on Foreign Relations. 
(1) It took 10,000 generations for the world to reach its first two billion people, in 1930. It took only one generation to reach the next two billion, in $1980 .^{13}$

(2) Every ninety-six hours, the world will have one million more residents. That is a new Pittsburgh or Boston every two days, a new Germany every eight months, a new Mexico or two new Canadas every year, and a new Africa and Latin America combined during the decade of $1990 .^{14}$

(3) From the time of Christ, it took eighteen centuries for the Earth to reach its first one billion people, but only one century to reach its second billion, and only one decade to reach its latest billion. ${ }^{15}$

Predicting the level at which the world population will peak is difficult. Achieving population stabilization and sustainable development requires that the world population reach replacement level. This occurs when each couple replaces itself. Replacement level equals 2.1 children per family. ${ }^{16}$ Currently, the world birth rate is 3.9 children per family, even though rates have fallen below replacement level in North America and Europe. ${ }^{17}$ In Asia and Latin America, each family has 3.2 children; however, in Africa families have more than six children per couple. ${ }^{18}$

Compounding the problem of high birth rates is the fact that in developing countries thirty-six percent of the population is under the age of fifteen. ${ }^{19}$ More than a third of the population is just beginning its reproductive years. This gives rise to the problem of "population momentum." Even if the world population reached replacement level today, it would skyrocket for decades to come. ${ }^{20}$ For example, Japan reached replacement level in 1957, but it will not reach zero population growth until $2006{ }^{21}$

To reach replacement level fertility, each country progresses through a four-stage demographic transition. Stage one begins in pre-industrial societies,

13. MOFFETT, supra note 11 , at 7 . This description of the phenomenal growth of the world population was first invoked by U.S. President Bill Clinton.

14. Id.

15. $I d$.

16. Rohrbough, supra note 5, at 235; MOFFETT, supra note 11 , at 8 .

17. Rohrbough, supra note 5, at 235.

18. Id. From 1985-1990, fertility ranged from an estimated 1.3 children per woman in Italy to 8.5 children per woman in Rwanda. 1994 Population Report, supra note 1, at 35, para. 6.2 .

19. 1994 Population Report, supra note 1, para. 6.6., at 36.

20. MOFFETT, supra note 11, at 8; Rohrbough, supra note 5, at 235; and 1994 Population Report, supra note 1, at 18, para. 3.2.

21. MOFFETT, supra note 11 , at 8. 
where both birth and death rates are high, keeping the population stable. After a country achieves improved living conditions, the country moves into the second stage where death rates begin to fall, but birth rates remain high because families still require a large number of children for farm labor and old-age security for parents. Most African nations are in stage two of their development. ${ }^{22}$

As living conditions continue to improve, urbanization occurs, the status of women improves and the cost-benefit analysis for child bearing shifts in favor of smaller families. Parents do not need large families for farm work and old-age security, but instead must educate their children, which increases the cost of raising a large family. A number of countries, particularly Latin American countries, are advancing through stage three. ${ }^{23}$

As a country moves from stage three into stage four, birth and death rates again reach parity, and population stabilizes. Most of the countries in Western Europe and North America have completed this transition. A few "developing countries," particularly South Korea and Thailand have also done so. ${ }^{24}$

The world must reach replacement level fertility to have sustainable development. As defined in the 1994 Population Report, "sustainable development implies, inter alia, long-term sustainability in production and consumption . . . to optimize ecologically sound resource use and minimize waste."25 $^{25}$

\section{B. Is There a Limit to Growth or Does Population Growth Lead to} Economic Growth?

Two competing theories vie for dominance in the population debate. The first, and the one that has achieved the most wide-spread support in policy circles and the media, holds that population growth intensifies environmental degradation and exhausts natural resources. According to this view, the world population will exceed the earth's carrying capacity, and the world will undergo massive starvation to realign population with finite natural resources. The competing view, sometimes referred to as the "revisionist" view" or the "supplyside demographic" view, ${ }^{27}$ finds that population growth has a neutral or even a positive influence on society. ${ }^{28}$ It holds that population growth encourages

22. Id. at 10 .

23. Id.

24. Id.

25. 1994 Population Report, supra note 1, at 18, para 3.3.

26. Andrew D. Ringel, The Population Policy Debate and the World Bank: Limits to Growth vs. Supply-Side Demographics, 6 Geo. Int'l Envt'l. L. Rev. 213, 215 (1993); MOFFETT, supra note 11, at 106.

27. Ringel, supra note 26 , at 214 . Ringel refers to this view as both the "revisionist" view and the "supply-side demographic" view.

28. MOFFETT, supra note 11 , at 107. 
economic development through technological innovation and more efficient resource allocation. According to this view, the world population will never exceed its carrying capacity. The scarcity of natural resources will encourage the development of new technologies and will stimulate the development of substitutes to replace the need for scarce resources. ${ }^{29}$ Evidence supports both views.

\section{Limits to Growth}

The first view, often referred to as the "limits to growth" theory, has as its forefather English political economist Thomas Malthus, who in 1798 wrote Essay on the Principle of Population..$^{30}$ Malthus predicted that population would expand geometrically, doubling every twenty-five years. However, because of limited natural resources, food production would not keep pace with increased demand. Ultimately, he concluded that the world population would reach the limits of sustainability and would be checked by famine, disease and war. ${ }^{31}$

Malthus' position was followed and popularized in the conventional wisdom ${ }^{32}$ by Stanford University biologist Paul R. Ehrlich in his 1968 book The Population Bomb. ${ }^{33}$ Ehrlich expanded Malthus' theory to include the effects of rapid population growth on the availability of other natural resources, such as water and energy, and on the earth's ability to absorb increasing waste, such as pollution. $^{34}$

Although neither of these predictions have developed, ample evidence supports the theory that the Earth has a certain "carrying capacity" which may be reached in the future. "Carrying capacity is the largest number of any given species that a habitat can support indefinitely." 35 If the carrying capacity is

29. Id.

30. Thomas R. Malthus, AN Essay OFthe PRINCIPLE of PopUlation OR a ViEw of Its PAST AND PRESENT EFFeCts On HuMAN HAPPINEss (6th ed. Ward, Lock and Company, 1890).

31. Id. at 4-7. Malthus' Essay was a response to the optimistic writers of the sixteenth and seventeenth centuries who applauded the growth in population as a way to increase markets and wealth for the newly industrialized Europe. However, Malthus saw extensive poverty in England, which suffered from a series of economic crises and bad harvests. MOFFETT, supra note 11, at 102. See also Ringel, supra note 26, at 217 (succinctly discussing Malthus' hypothesis).

32. The book sold 3 million copies and brought Ehrlich and his doomsayer position into the media limelight with an appearance on the Johnny Carson Show in 1970. MOFFETT, supra note 11 , at 109 .

33. Paul R. Ehrlich, The Population Bomb, (rev. ed. 1971).

34. Ringel, supra note 26, at 219.

35. Sandra Postel, Carrying Capacity: Earth's Bottom Line in STATE OF THE WORLD 1994: A WORLDWATCH INSTITUTE REPORT ON THE PROGRESS TOWARD A SUSTAINABLE SOCIETY 3,3 (1994). 
surpassed, the resource base and population decline. ${ }^{36}$ In the 1994 edition of the Worldwatch Institute's State of the World, author Sandra Postel illustrates a breach of carrying capacity with the following example: In 1944, twenty-nine reindeer were introduced to St. Mathew Island in the Bering Sea. By 1963, the number of reindeer had grown to over 6,000 deer. However, due to overgrazing the animals faced extensive competition for limited food supplies during a severe winter, and the population "crashed," leaving less than fifty reindeer. ${ }^{37}$

Although the world population will not "crash" as the reindeer population $\mathrm{did}^{38}$ evidence shows that the earth's carrying capacity may be reaching its limit. The earth's capacity to support the world's population is determined by a combination of food requirements, consumption levels, waste generated and available technologies. ${ }^{39}$

Evidence shows that the amount of available natural resources per person in the world is falling. ${ }^{40}$ Assuming that the world's population increases by thirty-three percent by 2010 as is expected, the amount of cropland per person would decline by twenty-one percent, ${ }^{41}$ and even though rangeland is expected to increase by four percent by the year 2010 , the per capita gain would actually be

36. Id at 3-4.

37. Id. at 4.

38. Id.

39. Id.

40. LESTER R. BROWN, WORLDWATCh INSTITUTE, STATE OF THE WORLD 1994: A WORLDWATCH INSTITUTE REPORT ON PROGRESS TOWARD A SUSTAINABLE SOCIETY xv (1994). Between 1950 and 1984, as a result of the "Green Revolution", world grain production expanded 2.6-fold, outstripping population growth and increasing per capita grain harvest by $40 \%$. The world fish catch also increased tremendously, 4.6-fold, doubling the seafood catch per person. However, since 1984, these trends have reversed. By 1993, the fish catch per person had fallen by $7 \%$, and after 1984 , grain production fell behind population growth. Id. at 177 . See id at 177 197 for an in-depth discussion of trends and projections of world food production from 1950 to 2030. Brown discusses the impact of the development of fertilizer and hybrid seeds which caused the "Green Revolution" and the lack of current technological innovations available to sustain the "Green Revolution" into the next 40 years.

41. Postel, supra note 35, at 9. Between 1980 and 1990, cropland area worldwide expanded by just $2 \%$, thus any gains in food harvest resulted from an increase in yields from already producing land. Id. The problem with this is that cropland yields, through the use of fertilizer and hybrid varieties of seeds developed during the "Green Revolution," have climaxed. Farmers have found that increasing fertilizer is no longer increasing yields. Without new technologies to raise the yields of current land under cultivation, the amount of grain produced is not likely to increase. Brown, supra note 40 , at $180-187$. Further, cropland is being lost to industrial development. For example, between 1957 and 1990, China lost 35 million hectares of cropland, an area equal to all the cropland in France, Germany, Denmark and the Netherlands combined. Postel, supra note 35, at 9. Moreover, the cropland in production is losing its capacity to produce as a result of unsound management practices and overuse. The Global Assessment of Soil Degradation found that more than 550 million hectares are losing topsoil or undergoing other forms of degradation. Id 
a loss of twenty-two percent. ${ }^{42}$ The world fish catch, which a number of nations rely on heavily for protein in their diet, is expected to drop by ten percent per person by $2010 .^{43}$ Moreover, the amount of forests and woodlands which provide lumber and fuelwood for consumption, and harbor the world's biodiversity of plants and animals, is expected to shrink by seven percent by the year 2010 , which translates to a per capita drop of thirty percent. ${ }^{44}$ Further, twenty-six countries, particularly countries in the Middle East and Africa, have insufficient renewable water supplies to meet the needs of a moderately developed society. ${ }^{45}$

Different consumption patterns and standards of living between the developing world and the developed world alter the impact of population increases on the earth's carrying capacity. Ehrlich developed an analytical equation to describe this relationship: Impact $(I)=$ Population $(P) \times$ Affluence (A) $x$ Technology $(T){ }^{46}$ Thus, if one American consumes resources fifty times faster than one Bangladeshi, every additional American child displaces fifty potential Bangladeshi children. ${ }^{47}$ A good illustration of this is in the amount of energy used per person. The developed world uses much more energy per person than the developing world. Every person in the United States uses $10 \mathrm{kw}$ $(200,000 \mathrm{kcal} /$ day $)$, while people in developing countries use only $1 \mathrm{kw}(20,000$

42. Postel, supra note 35, at 10. Much of the world's rangeland is overgrazed. According to the Global Assessment of Soil Degradation, some 680 million hectares of land, $20 \%$ of the world's pasture and rangeland, has been overgrazed and is losing productivity. Id.

43. Id. at 11 . Even though the world fish catch has climbed rapidly since 1950 , it peaked in 1989, and the U.N. Food and Agriculture Organization estimates that all 17 of the world's major fishing areas have either reached or exceeded their natural limits. Nine are in serious decline. Id at 10-11.

44. Id at 12. Recent studies show that the world's forests shrunk by 130 million hectares between 1980 and 1990, an area larger than Peru. Id

45. Id. at 11. Water constraints also hamper food production. Food grown with the use of irrigation accounts for only $16 \%$ of the total cropland, but one-third of the

world's harvest. Irrigated land is expected to increase in total, but again considering an increase in population, per capita irrigated land would decrease by $12 \%$. Id. at 11-12.

46. Paul R. Ehrlich \& J.P. Holden, Impact of Population Growth, 171 SCIENCE 1212 (1974); J.P. Holden and Paul R. Ehrlich, Human Population and the Global Environment, 62 AM. SCIENTIST 282 (1974); Stephen Raucher, Book Note, 18 Ecology L.Q. 259 (1991) in Ringel, supra note 26 , at 219 n. 16 .

47. Russel Lawrence Barsh, Indigenous Peoples' Perspectives on Population and Development, 21 B.C. ENVTL. AFF. L. REV. 257, 258 (1994). . Barsh argues that determining whether the resource space available is allocated to an American child or a Bangladeshi child is a matter of relative power. The wealthy can protect their standard of living by ownership of resources. But the poor can force the wealthy to share their resources by threatening to produce more children who will consume remaining resources making them unavailable to the wealthy. Thus, the poor can ultimately lower the standard of living of the wealthy by producing more children and consuming more resources unless the wealthy countries share their wealth with the poor. 
$\mathrm{kcal} /$ day). ${ }^{48}$ Thus, increasing the U.S. population by 125 million is the equivalent of increasing the population of a developing country by 1.25 billion people. ${ }^{49}$

As a result of consumption patterns and population growth, the earth's natural resources will be depleted and the environment will be destroyed. Further, according to the limits to growth view, the earth will reach its carrying capacity.

\section{The Revisionist View: Supply-side Demographics}

The revisionist view counters by relying on technology. It proposes that even if population increases and the earth has a limited carrying capacity, the fact that the world is faced with a burden on the carrying capacity will cause new technologies to be developed to avoid overburdening the earth's carrying capacity.

The revisionist view has as its historical underpinnings in writings by Frenchman Condorcet who predicted that new technology will reduce the need for labor and will enhance the productivity of limited natural resources, such as land. ${ }^{50}$ Today, Julian Simon is Ehrlich's nemesis in the revisionist camp. He

48. Rohrbough, supra note 5, at 237.

49. Id This relationship can also be seen in food consumption patterns. Although most developing countries aspire to the diet of the western world, the world's population has foreclosed that possibility. The average American consumes 800 kilograms of grain per year, most of it indirectly through meat, while the average Italian consumes 400 kilograms of grain per year, most of it rice. Brown, supra note 40 , at 190 . At U.S. consumption levels, the world grain output could only sustain 2.75 billion people, half as many as are alive today. Id. At Italian consumption levels, it would support 5.5 billion people, the current population, and at the Indian level, world grain output could sustain 11 billion people. Id. Thus, to support the number of people in the world in 2030, the affluence of the world's diet must be reduced, given that the earth has a finite supply of natural resources.

The relationship between population and consumption is also apparent in the production of waste. The developed world produces two-thirds of all greenhouse gases, such as carbon dioxide, methane and nitrous oxide, from the burning of fossil fuels, while the developing nations produce one-third of greenhouse gas emissions from primarily agricultural practices, such as carbon dioxide from tropical deforestation and methane from rice cultivation and livestock. John $\mathrm{H}$. Gibbons, Energy and the Environment: Intersecting Global Issues, Decisionmaking in the Face of Uncertainty 9 ARIZ. J. INT'L \& COMP. L. 231, 233-34 (1992). Gibbons, a nuclear physicist, is Chairman of the Office of Technology Assessment, a nonpartisan analytical support agency of the U.S. Congress. As the developing world further industrializes, its use of fossil fuels will increase. Combining an increased use of fossil fuels with continuing population growth, the developing world's greenhouse emissions will escalate. Id. at 234. An increase in waste thus increases the burden on the carth's carrying capacity.

50. For example:

New instruments, machines, and looms can add to man's strength and improve at once the quality and accuracy of his productions, and can diminish the time and labor that has to be expended on them. The obstacles still in the way of this progress will disappear. A very small amount of ground will be able to produce a great quantity of supplies. 
argues that population growth positively affects society because it creates increased demand for goods, which expands markets and stimulates economic growth. ${ }^{51}$ Further, he argues that by creating scarcity, population growth develops invention." Again and again, temporary scarcities induced by the growth of population and income have induced the search for solutions which, when found, left us better off than if the scarcities had never arisen."

Evidence supports Simon's theory. In the 1960's and 1970's, technology started the "Green Revolution" and saved large portions of the developing world from famine. ${ }^{53}$ Scientists developed chemicals and hybrid seeds, which were more resistant to weather changes, bugs and weeds. As a result, food harvests increased dramatically. Worldwide grain output increased nearly twice as fast as population growth. $^{54}$

Nevertheless, trends show that the successes of the green revolution are coming to an end. The per capita production of food worldwide is falling. ${ }^{55}$ And the technology that rescued large portions of the developing world from starvation during the 1960's and 1970's has reached a point of diminishing returns. ${ }^{56}$ Further, the prospect of replacement technology is weak. ${ }^{57}$ Leading scientists from the National Academy of Sciences and the Royal Society of the United Kingdom do not foresee the development of technological innovation that could dramatically increase production yields in the near future. ${ }^{58}$

Further, technology cannot solve the world's problems, but can merely buy time while the world stabilizes population and reduces excessive consumption.

MOFFET, supra note 11, at 104 (quoting Marie Jean Antoine, et al., THE FUTURE PROGRess of THE HUMAN MIND (1795)).

51. Id at 112 (citing Julian Simon, Resources, Population, Environment: An Oversupply of False Bad News, 208 SCIENCE 1431-37 (1980)).

[M]ore people not only means the use of more resources but more units of creativity and productivity. More people compete creatively for ways to develop or find substitutes. Thus, the world's resources are not finite. Id. at 113.

52. Id.

53. Years earlier, Europe was similarly saved from starvation with the advent of advanced farming techniques. In the 17th century, farmers learned that manuring and crop rotation eliminated the need to let land lie fallow. Farmers throughout Europe began rotating cereal crops, such as wheat and com, with root crops, like turnips and cassava, and forage crops, such as clover to restore nitrogen to the soil. MoFFET, supra note 11, at 68-69.

54. Id at 69-70.

55. See supra note 40 .

56. Brown, supra note 40 , at 178-87. Food yields are no longer increasing simultaneously with heavier applications of fertilizer.

57. Id. at 186-87.

58. Id. Technology that could lower the cost of desalting seawater or that could redesign the photosynthetic process to enable it to convert solar energy into biochemical energy more efficiently could dramatically increase world food production; however, scientists do not believe a break through in these technologies will occur in the foreseeable future. 
Technology stretches the earth's carrying capacity, but cannot solve the carrying capacity problem. ${ }^{59}$ Ehrlich summarizes the flaws in revisionist thinking as follows:

It's like designing an airplane where you worry more about how many you can get on board than how many you can fly with. The attitude of let's just hope something comes along, that technology will save us, is fine if you want to play dice with the future of your children and grandchildren. ${ }^{60}$

\section{Influence on Population Policy}

Regardless of the view to which one adheres, both views have influenced U.S. and world population policies. The limits to growth view is institutionalized as the dominant view in the United Nations system, the World Bank, and the media ${ }^{61}$ For example, the 1994 Population Report framed the population issue in terms of environmental impact: "The everyday activities of all human beings, communities and countries are interrelated with population change, patterns and levels of use of natural resources, the state of the environment, and the pace and quality of economic and social development." ${ }^{162}$ Further, World Bank President and former U.S. Secretary of Defense Robert S. McNamara demonstrated his support for the limits of growth view when he addressed the 1984 World Population Conference in Mexico City. ${ }^{63}$ Clearly, the United Nations and other international government and nongovernmental organizations strongly support the view that population must be reduced to reach sustainable development.

However, the revisionist view has also influenced world population policies. In 1984 at the International Conference on Population in Mexico City, the United States, under the Reagan administration, officially adopted the revisionist view, declaring that population and growth did not impede economic development. ${ }^{64}$ Nevertheless, with a change in the U.S. presidency, the United

59. Postel, supra note 35 , at 4-5, 12-16.

60. MOFFETT, supra note 11 , at 111.

61. Ringel, supra note 26.

62. 1994 Population Report, supra note 1, para. 3.1, at 18.

63. Ringel, supra note 26.

64. Id. U.S. Delegate James Buckley stated, "The relationship between population growth and economic development is not a negative one. Indeed, both in the American experience and in the economic history of most advanced nations, population growth has been an essential element in economic progress." Policy Statement of the United States of America at the International Conference on Population 2d Session, Mexico, D.F., at 6-13 (Aug. 1984) quoted in MOFFETT, supra note 11, at 283-84. 
States reversed its position and re-adopted the limits to growth philosophy concerning population growth. ${ }^{65}$

The limits to growth philosophy, which advocates sustainable development, directly impacts world population policies. In fact, the mandate of the 1994 Population Conference was to address the interrelationships between sustainable development, sustained economic growth and population. ${ }^{66}$ As sustainable development influences world policies, it necessarily affects the international customary right to reproductive choice.

\section{CUSTOMARy LAW RECOGNIZES AN INTERNATIONAL HuMAN RIGHT TO REPRODUCTIVE CHOICE}

The practice that "all couples and individuals have the basic right to decide freely and responsibly the number and spacing of their children and to have the information, education and means to do $\mathrm{so}^{\mathbf{9 6 7}}$ has ripened into a rule of customary international law.

\section{A. The Nature of Customary Law}

The body of international law derives from four sources: treaties, customary law, general principles of law recognized by civilized nations and "judicial decisions and teachings of the most highly qualified publicists of the various nations. ${ }^{108}$ Generally, international law develops in two ways (1) by the practice of states, known as "customary law," and (2) by agreement among states, known as "conventional law."

65. John M. Goshko, Planned Parenthood Gets Aid Grant, WASH. Post, Nov. 23, 1993, at $\mathrm{A} 12-13$.

66. 1994 Population Report, supra note 1, at 14.

67. Id. at 15 .

68. Stat. I.C.J. art. 38(1). Article 38(1) provides:

The Court, whose function is to decide in accordance with international law such disputes as are submitted to it, shall apply:

(a) international conventions, whether general or particular, establishing rules expressly recognized by the contesting states;

(b) intemational custom, as evidence of a general practice accepted

as law;

(c) the general principles of law recognized by civilized nations;

(d) ... judicial decisions and the teachings of the most highly qualified publicists of the various nations, as subsidiary means for the determination of rules of law.

Id. See also Restatement (THIRD) OF FoREIGN LAW of THE UNITED STATES $\$ 102$ (1987) [hereinafter RESTATEMENT (THIRD)]; RESTATEMENT (THIRD) \& 102 reporters' note 1.

69. Id. (introductory note). 
Customary law develops from a "general and consistent practice" followed by states from a "sense of legal obligation." The International Court of Justice formulated the elements for customary law as follows:

The Party which relies on custom ... must prove that this custom is established in such a manner that it has become binding on the other Party ... that the rule invoked by it is in accordance with a constant and uniform usage practiced by the States in question, and that this usage is the expression of a right appertaining to the State granting asylum and a duty incumbent on the territorial State .... ${ }^{1}$

\section{Elements of Customary Law}

To become customary international law, the custom must be a "constant and uniform usage practiced by the states." 72 Generally, a practice must reflect "wide acceptance" by the states, but the practice need not be universally followed. ${ }^{73}$ Further, contrary to earlier formulations of the rule, the practice need not continue for a long period of time. In the North Sea Continental Shelf Cases, the International Court of Justice acknowledged that "the passage of only a short period of time is not necessarily, or of itself, a bar to the formation of a new rule of customary international law." 74

In addition to being a "general and consistent practice,"75 the custom must be followed by states as a result of a legal duty or what is often called opinio juris et necessitatis. ${ }^{76}$ The fact that states consistently act in a certain manner is not sufficient to form customary law, unless they act under a sense of legal obligation. ${ }^{7}$ Often, states do not act with acknowledged compliance with the rules of international law, ${ }^{78}$ thus, legal obligation is inferred from acts or omissions. ${ }^{79}$

70. Id. $\$ 102(1)(2)$.

71. Asylum Case (Colom. v. Peru), 1950 I.C.J. 276, 276.

72. Id.

73. RESTATEMENT (THIRD), supra note $68, \$ 102 \mathrm{cmt} . \mathrm{b}$.

74. North Sea Continental Shelf Cases (F.R.G. v. Den. \& Neth.), 1969 I.C.J. 3, 44 [hereinafter North Sea Concinental Shelf Cases]. Earlier definitions of customary law implied that states were required to practice a custom for a long period of time before it would develop into law. RESTATEMENT (THIRD), supra note 68, $\$ 102$ reporters' note 2.

75. Id. \& 102(2).

76. Ian Brownlie, Principles of Public International Law 7 (4th ed., 1990).

77. North Sea Continental Shelf Cases, 1969 I.C.J. at 44. In this case, the Court stated: "The States concerned must therefore feel that they are conforming to what amounts to a legal obligation. The frequency, or even habitual character of the acts is not itself enough." Id.

78. BROWNLIE, supra note 76 , at 7.

79. RESTATEMENT (THIRD), supra note $68, \$ 102 \mathrm{cmt}$. c. 


\section{Evidence of Customary Law}

States act both internationally and domestically. In the international arena, a state may enter into international agreements that create law among the signatory states. ${ }^{80}$ However, international agreements may also create customary law for those states that are not parties. ${ }^{81}$ For example, where a multilateral agreement is designed for adherence by states generally, is widely accepted and is not rejected by a significant number of important states, it may become law for non-party states that do not actively dissent. ${ }^{82}$

Another state practice in the international arena that builds customary law is action in or through international organizations. The adoption of United Nations' resolutions, declarations and other statements of principles evidences and contributes to the development of customary international law. ${ }^{83}$

States also act through national domestic laws. Typically, a general principle of law recognized by civilized nations is an independent source of international law. ${ }^{84}$ However, it also may be evidence of customary law. Trends in domestic laws can establish international laws. ${ }^{85}$

\section{The Effect of Customary Law}

Customary international law is enforceable. The International Court of Justice applies international conventions, international custom, general principles of law and judicial decisions and teachings of national scholars as sources of law. ${ }^{86}$ Customary law and treaty law are equally binding on states within the

80. See North Sea Continental Shelf, 1969 I.C.J. at 28-29, 37-43. International agreements by themselves also create international law that binds the party states. Stat. I.C.J. art. $38(1)(1)$.

81. See Article 38 of the Vienna Convention on the Law of Treaties, which provides that "[n]othing in Articles 34 to 37 precludes a rule set forth in a treaty from becoming binding upon a third state as a customary rule of intemational law, recognized as such." Vienna Convention on the Law of Treaties, opened for signature May 23, 1969, U.N. Doc. AVCONF,39/27 (in force Jan. 27, 1980) U.N.T.S. 331, reprinted in 8 I.L.M. 679 (1969).

82. RESTATEMENT (THIRD), supra note $68, \$ 102 \mathrm{cmt}$. i.

83. Id. \& 102 reporters' note 2 . Recently at international conferences, states have been reaching agreement by consensus, rather than by vote. Such was the case at the 1994 Population Conference. 1994 Population Report, supra note 1, at 4.

84. Stat. I.C.J. art. 38(1)(c).

85. RESTATEMENT (THIRD), supra note $68, \$ 102$, reporters' note 7 . For example, a rule against torture is a part of international law because it is a principle common to all major legal systems.

86. Stat. I.C.J., art. 38(1). Article 38(1) provides:

The Court, whose function is to decide in accordance with international law such disputes as are submitted to it, shall apply:

(a) international conventions, whether general or particular, establishing rules expressly recognized by the contesting states; 
international arena. ${ }^{87}$ Once established as customary international law, a law is generally binding upon all states, even those states that enter the international arena after a practice has ripened into a rule of international law. ${ }^{88}$

Nations treat international law as law and consider themselves bound by it. They consider international law a legal obligation and are concerned about the consequences of its violation. ${ }^{89}$ Often, international law is observed because states have a common interest in maintaining particular standards and in avoiding the consequences of its violation. This is particularly true where damage to their "credit" or reputation might result. ${ }^{90}$

In the case of the right to reproductive freedom, once it ripens into customary international law, it binds all the states of the world. This is significant because prior to becoming a rule of international law, this right was only enforceable upon those nations that were signatories to the United Nations Convention on the Elimination of All Forms of Discrimination Against Women. ${ }^{91}$ As of 1993, only 122 states had signed the Women's Convention..$^{92}$ Although the United States is a signatory to the Women's Convention, the United States is not bound by it because it has not been ratified by the U.S. Senate. ${ }^{93}$ A number of states are not parties to the Women's Convention, including the United States. Nevertheless, the ripening of the right to reproductive choice into a rule of customary law significantly expands the enforceable rights of women throughout the world. All states are now bound to uphold the right of all couples and individuals to freely and responsibly decide the number and spacing of their children, and to have the information, education and means to do so.

(b) intemational custom, as evidence of a general practice accepted as law;

(c) the general principles of law recognized by civilized nations;

(d) ... judicial decisions and the teachings of the most highly qualified publicists of the various nations, as subsidiary means for the determination of rules of law.

Id.

87. RESTATEMENT (THIRD), supra note $68, \$ 102 \mathrm{cmt}$. j.

88. Id. $\$ 102 \mathrm{cmt}$. d.

89. Id. pt. I, ch. 1 , introductory note.

90. Id.

91. Canvention on the Elimination of All Forms of Discrimination Against Women, G.A. Res. 34/180, U.N. GAOR, 34th Sess., Supp. No. 46, at 193, U.N. Doc. A/RES/34/180 (1979) reprinted in 18 DUSAN J. DJONOVICH, UNITED NATIONS RESOLUTIONS, RESOLUTIONS ADOPTED BY THE GENERAL ASSEMBLY 381 (1975) [hereinafter Women's Convention].

92. Boland, supra note 4 , at 94 n.2.

93. Hernandez, supra note 4 , at $n .148$. 


\section{B. International Documents Recognize an International Human Right to Reproductive Choice}

The right to reproductive choice is "a general practice accepted by law,"94 and as such, is customary law. International practice sufficient to form custom is evidenced by international documents. ${ }^{95}$ Since 1968 , numerous international documents have recognized the right to reproductive choice.

The right to reproductive choice was first declared a human right by the international community in 1968 in the Proclamation of Teheran. ${ }^{\% 6}$ The right to reproductive choice was not formally guaranteed in the Universal Declaration on Human Rights, although article 16 did recognize the right of "men and women of full age" to "marry and found a family." "97 As formulated in the Proclamation of Teheran, the right recognized that "[p]arents have a basic human right to determine freely and responsibly the number and spacing of their children [and a right to adequate education and information in this respect.]" ${ }^{\prime 98}$ Just one year later in 1969, the international community reaffirmed its commitment to this right in the Declaration on Social Progress and Development. ${ }^{99}$ This document provides that "[p]arents have the exclusive right to determine freely and responsibly the number and spacing of their children." 100

The next international document to address the right to reproductive

94. Stat. I.C.J. art. 38(1). See also infra part II.A. and accompanying notes.

95. See infra part II.A.2. and accompanying notes.

96. United Nations Conference on Human Rights, Teheran, Apr. 22 to May 13, 1968, Proclamation of Teheran, art. 16, reprinted in Official Documents: United Nations Conference on Human Rights, 63 AM. J. INT'L. L. 674 (1969) [hereinafter Proclamation of Teheran].

97. The Universal Declaration of Human Rights, G.A. Res. 217A (III), U.N. GAOR, art. 16, U.N. Doc. A/810, (1948).

98. Proclamation of Teheran, supra note 96, art. 16.

Believing that it is timely to draw attention to the connection between population growth and human rights [the conference]:

....

3. Considers that couples have a basic human right to decide freely and responsibly on the number and spacing of their children and a right to adequate education and information in this respect;

4. Urges Member States and United Nations bodies and specialized agencies concerned to give close attention to the implications for the exercise of human rights of the present rapid rate of increase in world population.

ld.

99. Declaration on Social Progress and Development, G.A. Res, 2542 (XXIV), U.N. GAOR (1968), in 12 DUSAN J. DJONOVICH, U.N. RESOlUTIONS: RESOlUTIONS ADOPTED BY THE GENERAL AsSEMBLy 257 [hereinafter Declaration on Social Progress].

100. Id at 258. Article 4 provides: "The family as a basic unit of society and the natural environment for the growth and well-being of all its members, particularly children and youth, should be assisted and protected so that it may fully assume its responsibilities within the community. Parents have the exclusive right to determine freely and responsibly the number and spacing of their children." 
freedom was the World Population Plan of Action adopted by consensus at the United Nations World Population Conference in Bucharest, Romania, in 1974. ${ }^{101}$ This was the first international conference assembled to confront the perceived problem of over-population and environmental degradation. ${ }^{102}$ Faced with an increasingly expanding population, the states of the world again adhered to the general premise that couples have a right to reproductive choice. Article 14(f) provides:

All couples and individuals have the basic right to decide freely and responsibly the number and spacing of their children and to have the information, education and means to do so; the responsibility of couples and individuals in the exercise of this right takes into account the needs of their living and future children, and their responsibilities towards the community. ${ }^{103}$

The same year as the Bucharest Conference, the international community adopted the Resolution of the World Food Conference, which addressed the right to reproductive choice. ${ }^{104}$ Specifically, Resolution IX provided:

The World Food Conference .... Now calls on all Governments and on people everywhere ... to support ... rational population policies ensuring to couples the right to determine the number and spacing of births, freely and responsibly, in accordance with national needs within the context of an over-all development strategy. ${ }^{105}$

Shortly after these conferences, world leaders met in Mexico in 1975 for the World Conference on the International Women's Year. ${ }^{106}$ Again, the international community addressed the right to reproductive choice. Here, the right was stated as:

Every couple and every individual has the right to decide freely and responsibly whether or not to have children as well as to determine

101. Report of the World Population Conference, art. 14(f) U.N. Doc. E/CN. 60/19 (1974) [hereinafter 1974 Plan of Action].

102. Interestingly, the developed countries of the world thought population was an issue. The developing countries contended that the developed world's industry and heavy consumption of natural resources, not the developing countries' population, caused the degradation of the earth. Boyce Renseberg, As Birthrates Fall, Population Rises: U.N. Cairo Conference to Address World Growth Stabilization Efforts, WASH. POST, Sept. 4, 1994, at A1.

103. 1974 Plan of Action, supra note 101, art. 14(f).

104. Report of the World Food Conference, Res. IX, U.N. Doc. E/CN.65/20 (1974).

105. Id.

106. Report of the World Conference on the Intemational Women's Year, art. 12, U.N. Doc. E/CN. 66/34 (1975) [hereinafter Women's Convention]. 
their number and spacing, and to have information, education and means to do so. ${ }^{107}$

These initial formulations of the right to reproductive choice are neither consistent nor all inclusive. The right as described in the Proclamation of Teheran grants the right to "couples," while the Declaration on Social Progress gives the right to "parents". and the 1974 Plan of Action allows the right to be exercised by "all couples and individuals." Further, the Declaration on Social Progress and the Report of the World Food Conference fail to include the phrase "and a right to adequate education and information in this respect" which was included in the Proclamation of Teheran, the 1974 Plan of Action and the Declaration on International Women's Year. These inconsistencies clearly demonstrate that the right to reproductive choice as a form of customary law was not solidified at this early stage of development.

Yet, the states of the world continued to adhere to the general premise that couples had a right to reproductive choice. By 1981, this right was embodied in the Women's Convention and for the first time became legally binding upon signatory states. ${ }^{108}$ The Women's Convention mandates that:

State Parties shall take all appropriate measures to eliminate discrimination against women in all matters relating to marriage and family relations and in particular shall ensure, on a basis of equality of men and women:

(e) The same rights to decide freely and responsibly on the number and spacing of their children and to have access to the information, education and means to enable them to exercise these rights; ${ }^{109}$

Thus, signatory states to the Women's Convention are legally bound to support the basic human right of reproductive choice.

As the right of reproductive choice became a legally enforceable human right, the formulation of the right also solidified. The language of the Women's Convention reaffirms the language and meaning used in the Proclamation of Teheran and the 1974 Population Plan. This consensus on the fact that "couples and individuals" have the right to decide the number and spacing of children, and that they are entitled to "information, education and means" to exercise this right,

107. Id.

108. Id. art. 16(e). See also infra, part Il.A.3. and accompanying notes; Honoring Human Rights, supra note 4, at 94 n.2; and Hernandez, supra note 4, at 340 n. 148.

109. Id. 
establishes strong evidence that this international practice is developing into customary law.

In 1984, the international states further solidified their adherence to the basic human right of reproductive freedom when they convened in Mexico City for another conference on population and environmental degradation. ${ }^{110}$ At this conference, the international community recognized the right to reproductive choice as a basic human right and elaborated on this right by proclaiming that "[t]he ability of women to control their own fertility forms an important basis for the enjoyment of other rights." 111 Emphasizing this, the states expanded the right to reproductive choice by reiterating that education and the means to exercise the right are necessary to effectively ensure the right of reproductive choice. Recommendation 24 admonishes governments because, although the right was "widely accepted," they were not providing couples and individuals with the necessary education and services required to exercise the right. ${ }^{112}$

110. As the developing world underwent significant increases in population between 1974 and 1984, the dialogue between the developing world and the developed world significantly changed. In fact, the developing countries requested another world population conference, whereas in 1974, the developed nations requested such a conference. Report of the International Conference on Population, U.N. Department of Technical Co-operation for Development, 12th plen. mtg., at 51, U.N. Doc. E/CONF.76/19 (1984) [hereinafter 1984 Recommendations]. However, the United States adopted the revisionist view espoused by Julian Simon which holds that population growth is a positive societal force because it creates an increase in the demand for goods, expands markets and stimulates economic growth. MOFFETT, supra note 11, at 112.

The twenty-second paragraph of the Mexico City Declaration on Population and Development succinctly summed up the message of Mexico City:

At Bucharest, the world was made aware of the gravity and magnitude of the population problems and their close interrelationship with economic and social development. The message of Mexico City is to forge ahead with effective implementation of the World Population Plan of Action aimed at improving standards of living and quality of life for all peoples of this planet in promotion of their common destiny in peace and security.

1984 Recommendations, supra note 110 at 51.

111. Id. at 16.

112. Id. Specifically, Recommendation 24 states:

The World Population Plan of Action recognizes, as one of its principles, the basic human right of all couples and individuals to decide freely and responsibly the number and spacing of their children. For this right to be realized, couples and individuals must have access to the necessary education, information and means to regulate their fertility, regardless of the overall demographic goals of the Government. While this right is widely accepted, many couples and individuals are unable to exercise it effectively, either because they lack access to information, education and/or services or because, although some services are available, yet an appropriate range of methods or follow-up services are not. Indeed, data from the World Fertility Survey for developing countries indicate that, on average, over one fourth of births in the year prior to the Survey had not been desired. In addition, the decline in the prevalence of certain traditional practices, such as prolonged breast-feeding and post-partum abstinence, has increased the relative importance 
The international community next addressed the right to reproductive choice in 1985 in the Nairobi Strategies. ${ }^{113}$ In this international document, states urged governments to make available "as a matter of urgency" information and education to assist individuals and couples to exercise their right to reproductive choice. ${ }^{114}$

By 1994, at the U.N. International Conference on Population and Development in Cairo, Egypt, the right to reproductive choice was well- defined. The 1994 Population Report adopted the previously accepted language to define the right. Specifically, Principle 8 provides "[a]ll couples and individuals have the basic right to decide freely and responsibly the number and spacing of their children and to have the information, education and means to do so."115

Thus, "all couples and individuals," rather than "parents" or merely "couples," could exercise the right. Further, the international community affirmed that the right to reproductive choice necessarily includes the right to "education, information and means" to exercise the right. Moreover, the states emphasized that the enjoyment of other basic human rights depends upon the effective exercise of the right to reproductive choice.

At the 1994 Population Conference, 179 states, including the Holy See, by consensus reaffirmed their support for the right to reproductive choice. ${ }^{116}$ Only six countries in the world refused to send delegates to the 1994 Population Conference. ${ }^{117}$

Nearly every state in the international community displayed its support for the right to reproductive choice by adopting by consensus the 1994 Population Report. Further, since 1968, numerous United Nations documents accepted by the international community have recognized the human right to reproductive choice. As international documents demonstrate international practice, the universal acceptance of these international instruments demonstrates that the right to reproductive choice is "a general practice accepted by law." 118 As such, the right to reproductive choice is a customary international right.

Id.

of non-traditional family planning as a tool for the proper spacing of births.

113. Report of the World Conference to Review and Appraise the Achievements of the United Nations Decade for Women: Equality, Development and Peace, Nairobi at 39, U.N. Doc. A/CONF. 116/28/Rev. 1 (1985) [hereinafter Nairobi Strategies].

114. Id. at 39 , para. 157.

115. 1994 Population Report, supra note 1, at 15.

116. Id. at 120-122, "[The International Conference on Population and Development] affirms the application of universally recognized human rights standards to all aspects of population programmes." Id. at 13.

117. John Lancaster, Envoys to Population Meeting Try Compromise Wording on Abortion, WASH. POST, Sept. 5, 1994, at A21. Only Saudia Arabia, Lebanon, Sudan, Monaco, Liechtenstein and Iraq failed to send delegates. Id. See also 1994 Population Report. supra note 1 , at $120-22$.

118. Stat. I.C.J. art. 38(1). See also supra part II.A. and accompanying notes. 


\section{National Legislation Supports an International Human Right to Reproductive Choice}

A review of national legislation demonstrates that the right to reproductive choice is recognized as an international customary right. A general principle of law recognized by the major legal systems of the world evidences customary international law. ${ }^{119}$ Nearly universal support in national legislation for the right to reproductive choice demonstrates that the right is an international right recognized by customary law.

As of 1988 , of 170 countries in the world, only seven refused to support the right to reproductive choice by restricting access to contraceptives. ${ }^{120} 163$ states in the international arena have national legislation recognizing the right to reproductive choice as evidenced by legal access to contraceptives. ${ }^{121}$ Of the 163 countries supporting access to contraceptives, 125 offered direct financial support, while twenty-one offered indirect support. ${ }^{122}$ Seventeen countries, mainly developed countries, did not need to offer support for family planning programs because the private sector provided these services. ${ }^{123}$

Further, at least three countries have made the right to reproductive choice a fundamental right by constitutionalizing it. In 1974, Mexico amended Article 4 of its Constitution to provide "[e]very person has the right to decide in a free, responsible and informed manner on the number and spacing of their children."124 Brazil's 1988 Constitution also supports the right to reproductive freedom. Specifically, it provides:

Based on the principles of human dignity and responsible parenthood, family planning is a free choice of the couple, it being within the competence of the State to provide education and scientific resources for the exercise of this right, any coercion by official or private agencies being forbidden. ${ }^{125}$

119. RESTATEMENT (THIRD), supra note $68, \$ 102$, reporters' note 7 .

120. Population Trends and Policies in the 1980s, U.N. ESCOR, Population and Human Rights: Proceedings of the Expert Group Meeting on Population and Human Rights, Geneva, at 43, U.N. Doc. ST/ESA/SER.R/107 (1989) [hereinafter Population Trends].

121. Id.

122. Id.

123. Id. at 44 .

124. MEXiCAN CONSTITUTION, art. 4, reprinted in 12 CONSTITUTIONS OF the CoUnTRIES OF THE WORLD: MEXICO 13 (Albert P. Blaustein \& Gisbert H. Flanz eds., 1988).

125. CONSTITUICAO FEDERAL, ch. VII, Art. 226, p. 7 (Brazil) reprinted in Prieto, supra note 4. 
In the United States, the due process clause of the 14th Amendment to the Constitution guarantees the right to reproductive choice under the rubric of the right to privacy. In 1965, the United States Supreme Court in Griswold v. Connecticut ${ }^{126}$ struck down a state statute prohibiting the distribution of contraceptives because it violated the right to privacy guaranteed by the 14 th Amendment to the United States Constitution.

Nearly every country in the world supports the right to reproductive choice. This general principle of law recognized by the major legal systems of the world demonstrates that the right to reproductive choice is recognized as customary international law.

Universal support in national legislation and widespread consensus in international documents, conventions and treaties, particularly in the 1994 Population Report, shows that the right to reproductive choice is a "constant and uniform usage practiced by the states." 127 Clearly, the right to reproductive choice exists within international customary law.

\section{THE MEANING OF THE INTERNATIONAL HUMAN RIGHT TO REPRODUCTIVE CHOICE}

\section{A. The Information, Education and Means to Decide the Number and Spacing of Children}

For the past thirty years, the world has interpreted the phrase "information, education and means" to exercise the right to reproductive freedom to mean that women have a right to information about and access to contraceptives. ${ }^{128}$ Under the 1994 Population Report, the scope of this right was expanded to include the basic human right to education, ${ }^{129}$ the right to be free from gender-based discrimination ${ }^{130}$ and the right to sexual health. ${ }^{131}$ Although these rights had been guaranteed as basic human rights in other international documents, ${ }^{132}$ the 1994 Population Report included them as necessary rights to the fulfillment of the right to reproductive choice. However, the right to reproductive choice as described

126. Connecticut v. Griswold 381 U.S. 479 (1965).

127. Asylum Case, 1950 I.C.J. Rep. at 276.

128. See infra part III.A.1. and accompanying notes.

129. 1994 Population Report, supra note 1 at 25-28. See also infra part III.A.2.a. and accompanying notes.

130. Id. at 25-31. See also infra part III.A.2.b. and accompanying notes.

131. Id. at 43-54. See also infra part III.A.2.c. and accompanying notes.

132. For example, the basic human right to education was first enunciated in 1948 in the Universal Declaration of Human Rights. The Universal Declaration of Human Rights, supra note 97, at art. 26. 
in the 1994 Population Report and as developed in international law did not include the right to abortion. ${ }^{133}$

\section{Information About and Access to Contraceptives}

In the past, the right to reproductive freedom as practiced encompassed only the right to information about and access to contraceptives. After the adoption of the 1994 Population Report, this right has expanded, but it still includes the basic right to information about and access to contraceptives.

After the 1974 Plan of Action, governments throughout the developing world established family planning programs and clinics to distribute contraceptives. By 1988, 146 governments provided, either directly or indirectly, family planning services to their citizens. ${ }^{134}$ In addition to access to contraceptives, most countries provided information about the use of family planning methods. For instance, in Thailand, government-supported messages that large families make families poor infiltrate every aspect of the Thai life. As most Thai homes now have radios and some have televisions, government announcements carry the message, and soap opera story lines subtly reinforce the message. Village loud speakers broadcast announcements about the governmentrun family planning clinic, and the clinics themselves provide literature about the virtues of smaller families. ${ }^{135}$ Further, governments typically advocate the use of contraceptives. For example, in Zimbabwe, which has one of Africa's most successful family planning programs, the president appointed his sister-in-law to run the program for a brief period of time. ${ }^{136}$ The goal has been to change the historical, social and cultural opposition to smaller families and to alleviate stigmatization associated with the use of modern family planning. ${ }^{137}$

These family planning services have brought a drastic decline in the fertility rate in developing countries since the 1960s. In Thailand, the use of contraceptives increased from $15 \%$ to $67 \%$ of the couples from 1970 to 1987 , and the number of children dropped from 6.1 to just over two. Nearly $100 \%$ of Thai women know of at least one modern method of contraception. ${ }^{138}$ In Kenya, where the birth rate was as high as eight children per couple in 1970, the fertility rate has dropped to 5.4 children, and contraceptive use has increased from $6 \%$ to $33 \%$ since $1989 .{ }^{139}$ In Morocco, the fertility rate has dropped from 6.9 in 1980 to 4.5 children in $1991 .{ }^{140}$ In Indonesia, the use of contraceptives increased from

133. 1994 Population Report, supra note 1 at 61-62, para 8.25. See also infra part III.A.3.

134. Population Trends, supra note 120 , at 43.

135. MOFFETT, supra, note 11 , at 138.

136. Id at 152.

137. Id at 153.

138. Id. at 146.

139. Id. at 141.

140. Id. 
$10 \%$ percent to fifty percent of couples and the average number of children fell to four. ${ }^{141}$ The rate of contraceptive use by couples in Bangladesh has doubled to forty percent in the last ten years, and the fertility rate has dropped from 6.8 children to 4.2 children. ${ }^{142}$ In Peru, the number of children per couple has dropped to 3.5 since $1978 .^{143}$ In what has become known as a model of family planning success for sub-Saharan Africa, the use of contraceptives in Zimbabwe has tripled since 1980 . Currently, $43 \%$ of couples use family planning services. ${ }^{144}$

Worldwide, the increased use of contraceptives brought about through family planning programs has dropped the fertility rate from 6.1 to $3.9 .{ }^{145} \mathrm{Yet}$, the birth rate has stalled at this level, still above the replacement level of 2.1 children per family. ${ }^{146}$ Family planning programs from the 1960's to the 1980 's have played a significant role in reducing the fertility rate, but this effort alone is not sufficient to reach replacement level fertility. Women's empowerment is necessary to reach sustainable development. ${ }^{147}$

\section{Women's Empowerment to Exercise the Right}

Governments have focused solely on providing information about and access to contraceptives. They have not interpreted the right to reproductive choice to encompass programs to increase women's education, to eliminate gender-discriminatory laws or to provide for women's sexual health. ${ }^{148}$ However, the 1994 Population Report expands the right to reproductive choice to include the basic human right to education, ${ }^{149}$ the right to be free from gender-based

141. Boyce Rensberger, As Birthrates Fall, Population Rises U.N. Cairo Conference to Address World Growth Stabilization Efforts, WASH. PosT, Sept. 4, 1994, at A1.

142. Id.

143. Id.

144. Id.

145. Rohrbough, supra note 5.

146. Id.

147. 1994 Population Report, supra note 1, at 25, para 4.1.

The empowerment and autonomy of women and the improvement of their political, social, economic and health status is a highly important end in itself. In addition, it is essential for the achievement of sustainable development. . . . Experience shows that population and development programmes are most effective when steps have simultaneously been taken to improve the status of women.

Id.

148. Honoring Human Rights, supra note 4, at 99-103 (arguing that to reduce population growth governments should focus less on providing information about and access to contraceptives and focus more on empowering women, safe-guarding their basic human rights and providing for their sexual health, such as treatment for sexually transmitted diseases).

149. 1994 Population Report, supra note 1, at 25-28.

The empowerment and autonomy of women and the improvement of their political, social, economic and health status is a highly important end in itself. In 
discrimination ${ }^{150}$ and the right to sexual health. ${ }^{151}$

\section{a. The Right to Education}

"Education is one of the most important means of empowering women with the knowledge, skills and self-confidence necessary to participate fully in the development process."152 The empowerment and autonomy of women and the improvement of their political, social, economic and health status enhances their decision-making capacity at all levels in all spheres of life. ${ }^{153}$

Yet, even basic primary education is not available to some women and girls around the world. The United Nations estimates that 170 million children are not

addition, it is essential for the achievement of sustainable development. . . In addition, improving the status of women also enhances their decision-making capacity at all levels in all spheres of life, especially in the area of sexuality and reproduction. This, in turn, is essential for the long-term success of population programmes. Experience shows that population and development programmes are most effective when steps have simultaneously been taken to improve the status of women.

Id at 25 para. 4.1. "Education is one of the most important means of empowering women with the knowledge, skills and self-confidence necessary to participate fully in the development process." Id para. 4.2. at 14.

150. Id. at 25-31. "All human beings are born free and equal in dignity and rights." Id.

Since in all societies discrimination on the basis of sex often starts at the earliest stages of life, greater equality for the girl child is a necessary first step in ensuring that women realize their full potential and become equal partners in development. In a number of countries, the practice of prenatal sex selection, higher rates of mortality among very young girls, and lower rates of school enrollment for girls as compared with boys, suggest that son preference' is curtailing the access of girl children to food, education and health care. This is often compounded by the increasing use of technologies to determine foetal [sic] sex, resulting in abortion of female foetuses [sic]. Investments made in the girl child's health, nutrition and education, from infancy through adolescence, are critical.

Id. at 28, para 4.15 .

151. Id. at 43-54.

Reproductive health is a state of complete physical, mental and social well-being and not merely the absence of disease or infirmity, in all matters relating to the reproductive system and to its functions and processes. Reproductive health therefore implies that people are able to have a satisfying and safe sex life and that they have the capability to reproduce and the freedom to decide if, when and how often to do so.... It also includes sexual health, the purpose of which is the enhancement of life and personal relations, and not merely counselling and care related to reproduction and sexually transmitted diseases.

Id. at 43, para. 7.2.

152. Id. at 25 , para. 4.1 .

153. Id. 
enrolled in primary school and seventy percent of these children are girls. ${ }^{154}$ Further, 960 million people are illiterate, and two-thirds of these people are women. ${ }^{155}$ Eman Ibrahim and Khadra Gomaa are two such women. ${ }^{156}$ They live in Buram, a small farming village seventy miles southeast of Cairo, Egypt. Eman's father sent her brothers to school rather than her, and Khadra dropped out of school after third grade. ${ }^{157}$ Often, families fail to send their daughters to school because education is expensive and families prefer to educate their sons. ${ }^{158}$

The 1994 Population Report set goals for the empowerment of women through education. The target set by the U.N. for universal primary education in all countries is the year 2015. ${ }^{159}$ In addition, the 1994 Population Report urges governments to ensure "the widest and earliest possible" access by girls and women to secondary and higher levels of education. ${ }^{160}$ Further, the Report encourages governments, schools, the media and other social institutions to eliminate stereotypes and gender biases. ${ }^{161}$

Access to education is necessary to fully allow women the opportunity to exercise their right to reproductive freedom. The scope of this right necessarily includes the right to general education in addition to information about contraceptives. Education is imperative to the full integration of women in the political, social, economic and development institutions of society and is critical to the achievement of sustainable development and replacement level fertility.

\section{b. The Right to be Free from Discrimination and Violence}

"All human beings are born free and equal in dignity and rights."162 Yet, discrimination and violence against women and girls are rampant throughout the

154. Id. at 25 , para. 4.2 .

155. Id.

156. John Lancaster, Close to Cairo But Eons Away Population Conference Goals Meet Reality in Rural Village, WASH. POST, Sept. 9, 1994, at A29.

157. Id.

158. MoFFET, supra note 11, at 198. Pilot projects around the world work to circumvent families' reluctance to send girls to school. One such project by the Center for Women and Development in Dhaka, Bangladesh, provides girls with books and other school supplies and personal hygiene kits with soap, towels, lice-killing combs and five packages of vegetable seeds. The director of the program explains: "If a poor household has more access to vegetables and fruits there will be increased food in the household. If there is more food it means the girls will get their fair share to eat. If there is more food it also means her labor is less needed and the family won't mind letting her go off to school." Id.

159. 1994 Population Report, supra note 1, at 29, para. 4.18.

160. Id.

161. Id. at 29, para. 4.19. "Countries must recognize that, in addition to expanding education for girls, teachers' attitudes and practices, school curricula and facilities must also change to reflect a commitment to eliminate all gender bias, while recognizing the specific needs of the girl child." Id

162. Id. at 14. 
world. The World Health Organization indicates that women ages fifteen to forty-four lose more "Discounted Healthy Years of Life" to rape and domestic violence than they do to breast cancer, cervical cancer, obstructed labor, heart disease, AIDS, respiratory infections, motor vehicle accidents or war. ${ }^{163}$

Discrimination against daughters and a preference for sons causes female infanticide and the abortion of female fetuses. Studies in India show that girls born to mothers who already have one or more surviving daughters have a fiftythree percent higher mortality rate than other children. ${ }^{164}$ Also, in a study of 8,000 abortions performed following amniocentesis in an Indian clinic, 7,999 of the fetuses aborted were female. ${ }^{165}$ In China, for every 100 girls born 118.5 boys are born. Nearly 1.7 million girls are missing each year. ${ }^{166}$

In addition to higher abortion rates of female fetuses, women endure discrimination, exploitation and violence. Take for example the plight of Dellnoor, a twenty-seven-year-old mother of six who lives in Dhaka, Bangladesh. ${ }^{167}$ Bangladesh's family planning programs are some of the best in the world, but Dellnoor is unable to use them. Following conservative custom, religion and law in Bangladesh, Dellnoor was given over in an arranged marriage to Habib following her first menstruation. Under the custom of purdah, she is forbidden, except on rare occasions and then only with another adult, to leave her ten-by-ten home that she shares with her six children and husband. Although she wants to use modern contraceptives, she is forbidden by Habib. "It's not my decision," she says. "He doesn't want family planning."168

Like Dellnoor, numerous women throughout the world succumb to the dictates of men concerning reproductive choices. The elimination of all kinds of discrimination and violence against women is essential to the effective exercise of the right to reproductive choice. The 1994 Population Report and the international community recognize the necessity of the elimination of discrimination and violence against women as an imperative part of the right to reproductive choice. ${ }^{169}$ Further, the right to reproductive choice encompasses the right to reproductive health.

163. Adrienne Germain, Sia Nowrojee \& Hnin Hnin Pyne, Setting a New Agenda: Sexual and Reproductive Health and Rights, in PopUlation Polices Reconsidered: Health, EMPOWERMENT, AND RIGHTS 26, 41 (Gita Sen, Adrienne Germain \& Lincoln C. Chen eds., 1994).

164. Population Trends, supra note 120, at 37.

165. MOFFETT, supra note 11 , at 217.

166. Honoring Human Rights, supra note 4, at 99.

167. See MOFFETT, sipra note 11, at 19496.

168. Id.

169. 1994 Population Report, supra note 1 at 25-31. "Advancing gender equality and equity and the empowerment of women, and the elimination of all kinds of violence against women, and ensuring women's ability to control their own fertility, are cornerstones of population and development programmes." Id. at 15. 


\section{c. The Right to Reproductive Health}

As recognized in the 1994 Population Report, the right to reproductive choice includes the right to sexual health. ${ }^{170}$ The 1994 Report defines reproductive health as

[A] state of complete physical, mental and social well-being and not merely the absence of disease or infirmity, in all matters relating to the reproductive system and to its functions and processes. ... It also includes sexual health, the purpose of which is the enhancement of life and personal relations, and not merely counselling and care related to reproduction and sexually transmitted diseases. ${ }^{171}$

Reproductive health care includes information and counselling about and access to: family planning methods; prenatal care, safe delivery and post-natal care; education about the prevention of and treatment for sexually transmitted diseases and infertility and information and counselling on human sexuality. ${ }^{172}$

Throughout most of the world, adequate reproductive health care is unavailable. About 500,000 pregnancy-related deaths occur every year, and for every such death, another 100 women suffer significant pregnancy complications with long-term physical and social consequences. ${ }^{173}$ Further, of the seven million perinatal deaths of children worldwide, about half are associated with low birth weight resulting from maternal malnutrition, anemia and sexual transmitted diseases. ${ }^{174}$ Moreover, women are at higher risk for sexually transmitted diseases than men. ${ }^{175}$ For example, Han'a, who lives in Egypt, is sixteen-years-old and has been married for two years. ${ }^{176}$ She contracted syphilis and was treated but

170. Id. at 43, para. 7.3.

[R]eproductive rights embrace certain human rights that are already recognized in national laws, international human rights documents and other consensus documents. These rights rest on the recognition of the basic right of all couples and individuals to decide freely and responsibly the number, spacing and timing of their children and to have the information and means to do so. ...

Id.

171. Id. at 43 , para. 7.2 .

172. Id. at 44, para. 7.6.

173. Iain Aitken \& Laura Reichenbach, Reproductive and Sexual Health Services: Expanding Access and Enhancing Quality in Population Poucies Reconsidered: Health, EMPOWERMENT, AND RIGHTS 177, 178 (Gita Sen, Adrienne Germain \& Lincoln C. Chen eds., 1994) [hereinafter Sexual Health Services].

174. Id.

175. Id. at 179.

176. Id. at 188 . 
was reinfected by her husband. She knew nothing about sexually transmitted diseases and did not realize that her husband could infect her. ${ }^{177}$

Adequate reproductive health care is essential for women to effectively exercise their right to reproductive choice. The 1994 Population Report directs all countries to make adequate reproductive health available by the year $2015 .{ }^{178}$ Sexual and maternal health is necessarily included within the right to reproductive choice.

\section{No Right to Abortion}

Although the right to reproductive choice includes the right to reproductive and sexual health, it does not include the right to an abortion. The issue of whether the right to reproductive choice as accepted in customary international law includes the right to abortion has been hotly debated. However, following the adoption of the 1994 Population Report, it is clear that the right to reproductive choice does not include the right to an abortion.

\section{a. Previous International Documents Relating to the Right to Abortion}

International documents relating to abortion neither prohibit nor endorse it. Twice the international community has refused to prohibit the right to an abortion by defining life as beginning at the point of conception. In the Universal Declaration on Human Rights, Article 3 guarantees that "[e]veryone has the right to life, liberty and security of person." 179 During the debates on this provision, two amendments were submitted to apply the article "from the moment of conception." However, the General Assembly refused to adopt these amendments and preferred a general formula not addressing this issue. ${ }^{180}$ With the adoption of the Covenant on Civil and Political Rights, the states of the world again refused to define conception as the beginning of life. ${ }^{181}$ An amendment to Article 6, which prohibits the execution of a pregnant woman sentenced to death, was introduced to protect the right to life "from the moment of conception." 182 The international community refused to recognize such a right and the

177. Id.

178. 1994 Population Report, supra note 1 at 44, para. 7.6.

179. The Universal Declaration of Human Rights, supra note 97, art. 3.

180. Relationship Between Human Rights and Population Issues: Standard-Setting Activities of the United Nations Organization, U.N. ESCOR, Population and Human Rights: Proceedings of the Expert Group Meeting on Population and Human Rights, at 54, U.N. Doc. ST/ESA/SER.R/107 (1989) [hereinafter Standard-Setting Activities of the U.N.].

181. Id.

182. See $i d$. at 61 for a discussion of the arguments made by both sides. 
amendment failed by a vote of thirty-one to twenty with seventeen abstentions. ${ }^{183}$ The documents of the United Nations do not prohibit the right to an abortion.

However, United Nations instruments do not endorse the right to abortion either. The Declaration on the Rights of the Child proclaims that children "[need] special safeguards and care, including appropriate legal protection, before as well as after birth."' ${ }^{84}$ Further, the 1984 Recommendations to the World Population Plan of Action adopted at the 1984 International Conference on Population urges governments "to take appropriate steps to help women avoid abortion, which in no case should be promoted as a method of family planning." 185 Significantly, in one of the first enunciations of the right to reproductive choice, the right was presented as not including the right to abortion. In the Declaration on Social Progress and Development, the "exclusive right" of parents "to determine freely and responsibly the number and spacing of their children" was presented by some sponsors as not encompassing the right to abortion. ${ }^{186}$

Plainly, previous international documents neither endorse the right to an abortion nor prohibit it. "International human rights law is not yet crystallized in this field." 187 As such, a right to abortion included within the right to reproductive choice is not a "constant and uniform usage practiced by the states" 188 to form a basis for international customary law.

\section{b. National Legislation on Abortion}

National legislation regarding abortion cannot form a basis for a "constant and uniform usage practiced by the states"189 to establish abortion as a part of the customary right to reproductive choice. Access to abortion is by no means universally recognized in the international community. Further, no trend in international abortion legislation has solidified.

Abortion upon the request of the mother, as legalized in the United States, ${ }^{190}$ is available in only a minority of countries. Of eighty-two countries

183. Id.

184. Declaration on the Rights of the Child, preamble (1959).

185. 1984 Recommendations, supra note 110, at 21, recommendation 18(e).

186. Standard-Setting Activities of the U.N., supra note 177, at 61 citing U.N. Doc. A/C.3/SR.1599, at 15, and U.N. Doc. A/C.3/SR.1682, at 3.

187. Standard-Setting Activities of the U.N., supra note 180 at 62 . See also Prieto, supra note 4, at 143 (1993). However, not all writers agree. See Hernandez, supra note 4 at 312 (arguing that intemational documents do support an inference that the right to reproductive choice includes the right to abortion).

188. Asylum Case, 1950 I.C.J. Rep. at 276.

189. Id.

190. Roe v. Wade, 410 U.S. 113 (1973) (the landmark case establishing a woman's right to abortion on demand. Holding that a woman's right to privacy under the 14th Amendment due process clause necessarily encompasses her decision whether to terminate a pregnancy before the end of the first trimester of pregnancy). Planned Parenthood of Southeastern Pennsylvania v. 
responding to a survey conducted by the Population Policy Data Bank, which is maintained by the United Nations, only eighteen countries provide abortion on demand. ${ }^{191}$ Of those countries that do not have legalized abortion upon request, most responding to the United Nations survey do authorize abortion in some circumstances. For example, nearly two-thirds of the nations responding allow abortion in cases of rape of the mother. ${ }^{192}$ However, seventeen countries do not allow abortion to protect the physical health of the mother. ${ }^{193}$ Finally, in six countries, abortion is not legal even to save the life of the mother. ${ }^{194}$

Moreover, the trend in abortion laws is not clear. While some countries are liberalizing strict abortion laws, other nations are enacting new constitutions or constitutional amendments to protect life from the point of conception. Canada, in 1988, found the criminalization of abortion unconstitutional, ${ }^{195}$ while Cuba, Togo, Vietnam and the People's Republic of China decriminalized abortion through criminal code amendments. ${ }^{196}$ Algeria, Burundi and Ghana now permit abortion when a mother's life or health is in danger, and Ghana also allows abortions in cases of rape, incest or severe physical deformities of the child. ${ }^{197}$ Greece and Czechoslovakia, in 1986, legalized abortion upon request during the first twelve weeks of pregnancy, ${ }^{198}$ while Cape Verde did the same in 1987. ${ }^{199}$ Malaysia, ${ }^{200}$ Saint Vincent and the Grenadines liberalized their abortion laws, adopting the English standard, which permits an abortion if a medical practitioner in good faith believes that continuation of the pregnancy would involve a greater risk to the mother's life or mental or physical health than if the pregnancy were terminated. ${ }^{201}$

Nevertheless, numerous countries have enacted stricter laws on abortion. In 1983, Ireland enacted a constitutional amendment explicitly acknowledging the

Casey, 505 U.S. 833, 112 S.Ct. 2791(1992) (reaffirming a women's right to terminate her pregnancy established under Roe, but modifying the point at which that right could be overcome by compelling state interests. Under Casey, a woman may terminate her pregnancy without interference from the state prior to the point of viability).

191. Population Trends, supra note 120, at 46.

192. Id. Only 46 countries permit abortion where the mother has been raped, while twentyeight do not.

193. Id.

194. Id.

195. Morgentaler v. The Queen, 44 D.L.R.4th 385 (1988).

196. Rebeoca J. Cook, Abortion Laws and Policies: Challenges and Opportunities, 1989 INT'L J. GYNECOLOGY \& OBSTETRICS 61 (Supp. 3, 1989), (Cuba prohibits abortion only if performed for profit, by an unqualified person, in an unofficial place or without the woman's consent. The national health care system provides abortion free of charge).

197. 12 AnNual Review of Population LaW xxxiii (Reed Boland ed., 1985).

198. 13 ANNUAL REVIEW OF POPULATION LAW xlii (Reed Boland, ed., 1986).

199. 14 ANNUAL REVIEW OF POPULATION LAW xxxix (1987).

200. 16 ANNUAL REVIEW of PopUlation LaW xxxviii (1989).

201. 15 annual Review of Population Law xxxviii (1988). 
right to life of the unborn, ${ }^{202}$ while Chile's Constitution, enacted in 1980, contains similar language. ${ }^{203}$ Further, the 1986 Philippine Constitution, ${ }^{204}$ the Constitution of Ecuador, ${ }^{205}$ and Guatemala's Constitution ${ }^{206}$ protect the life of the unborn from the moment of conception. Plainly, the various national laws on abortion are in conflict and do not represent a trend either toward the liberalization or the criminalization of abortion. Moreover, abortion upon the request of the mother is available in only a minority of states, and abortion is illegal, even to save the life of the mother, in at least six countries. The national laws on abortion do not demonstrate a "general practice"207 of the states upon which to base an international customary right to abortion.

\section{c. The 1994 Population Report}

Just as the national laws of the various states of the world cannot evidence an international right to abortion, the 1994 Population Report adopted at the 1994 Population Conference cannot demonstrate a worldwide, consistent, uniform practice supporting an international right to abortion. Prior to the 1994 Population Conference, international consensus on abortion, as demonstrated by United Nations' documents, was not solidified. ${ }^{208}$ However, with the adoption of the 1994 Population Report, an international consensus developed adopting the view that abortion is not included within the right to reproductive choice. ${ }^{209}$

202. CONSTITUTION OF IRELAND, art. 40 , sec. 3 reprinted in 9 CONSTITUTIONS OF THE COUNTRIES OF THE WORLD: IREL AND 132 (Albert P. Blaustein \& Gisbert H. Flanz eds., 1994), ("The State acknowledges the right to life of the unborn ....").

203. CONSTITUTION OF CHILE, ch. III, art. 19, reprinted in 4 CONSTITUTIONS OF THE COUNTRIES OF THE WORID: CHILE 41 (Albert P. Blaustein \& Gisbert H. Flanz, eds., 1991), ("The Constitution guarantees to all persons: 1. The right to life and to the physical and psychological integrity of the individual. The law protects the life of those about to be born").

204. Constitution of THE PHILIPPINES, art. II, sec. 12, reprinted in 15 Constitutions of THE COUNTRIES OF THE WORLD: PHILIPPINES, SUPP. 3 (Albert P. Blaustein \& Gisbert H. Flanz eds., 1986), ("The State . . . shall equally protect the life of the mother and the life of the unborn from conception ....").

205. CONSTITUTION OF ECUADOR, ant. 25, reprinted in 6 CONSTITUTIONS OF THE COUNTRIES OF THE WORLD: ECUADOR 16 (Albert P. Blaustein \& Gisbert H. Flanz eds., 1987), ("The child will be protected from conception ....").

206. Constitution of Guatemala, art. 3, reprinted in 7 Constitutions of THE COUNTRIES OF THE WORLD: GUATEMALA 27 (Albert P. Blaustein \& Gisbert H. Flanz eds., 1986), ("The State guarantees and protects human life from the time of its conception as well as the integrity and security of the individual.").

207. STAT. I.C.J. art. 38(1)(b).

208. See supra part III.A.3.a. and accompanying notes.

209. However, those supporting unrestricted abortion will, nonetheless, continue to push for an international consensus supporting an international right to abortion. At some point in the future, an international customary right to abortion may develop; however, in 1994, this right does not yet exist. 
First, the 1994 Population Report explicitly refuses to recognize any new human rights. One-hundred and seventy-nine nations joined in consensus to adopt the 1994 Population Report. ${ }^{210}$ The Preamble to the Report provides that "the International Conference on Population and Development does not create any new international human rights, [but] affirms the application of universally recognized human rights standards to all aspects of population programmes."211

Second, while the issue of abortion, particularly unsafe abortion, is directly addressed, the 1994 Report explicitly states the matter of abortion is to be dealt with by legislation at the national level. ${ }^{212}$ Moreover, the paragraph in the 1994 Report directly dealing with the issue of abortion, paragraph 8.25 , ad vocates that abortion should never be promoted as a method of family planning, and the prevention of unwanted pregnancies should be given the highest priority to eliminate the need for abortion. ${ }^{213}$

Further, although all nations joined in consensus to support the 1994 Population Report, a number of countries issued reservations regarding the issue of abortion. El Salvador, ${ }^{214}$ Ecuador, ${ }^{215}$ Malta, ${ }^{216}$ Paraguay, ${ }^{217}$ Argentina, ${ }^{218}$

210. 1994 Population Report, supra note 1, at 120-22.

211. Id. at 13 (emphasis added).

212. Id. at 61-62, para. 8.25.

213. Id. Specifically, paragraph 8.25 provides:

In no case should abortion be promoted as a method of family planning. All Governments and relevant intergovernmental and non-govermmental organizations are urged to strengthen their commitment to women's health, to deal with the health impact of unsafe abortion as a major public health concern and to reduce the recourse to abortion through expanded and improved family-planning services. Prevention of unwanted pregnancies must always be given the highest priority and every attempt should be made to eliminate the need for abortion. Women who have unwanted pregnancies should have ready access to reliable information and compassionate counselling. Any measures or changes related to abortion within the health system can only be determined at the national or local level according to the national legislative process. In circumstances where abortion is not against the law, such abortions should be safe. In all cases, women should have access to quality services for the management of complications arising from abortion. Postabortion counselling, education and family-planning services should be offered promptly, which will also help to avoid repeat abortions.

Id.

214. Id. at 136. Specifically, El Salvador entered the following oral reservation: Recognizing that aspects of the Programme of Action are tremendously positive and are of supreme importance for the future development of mankind, the family and our children, we, as leaders of nations, cannot but express the reservations we feel are appropriate. If we did not, we could not possibly face the question from our people that are certain to be posed.

...

We Latin American countries are signatories to the American Convention on Human Rights (Pact of San Jose). Article 4 thereof states quite clearly that life must be protected from the moment of conception. In addition, because our countries are mainly Christian, we consider life is given by the Creator and cannot 
and the Holy See ${ }^{219}$ objected to any reference to abortion because abortion

be taken unless there is a reason which justifies it being extinguished. For this reason, as far as Principle 1 of the Programme of Action is concemed, we associate ourselves with the reservation expressed by the delegation of Argentina: we consider that life must be protected from the moment of conception.

Id.

\section{Id. at 143-44. Specifically, Ecuador stated on the record:}

With regard to the Programme of Action of the Cairo International Conference on Population and Development and in accordance with the provisions of the Constitution and laws of Ecuador and the norms of intemational law, the delegation of Ecuador reaffirms, inser alia, the following principles embodied in its Constitution: the inviolability of life, the protection of children from the moment of conception, freedom of conscience and religion, the protection of the family as the fundamental unit of society, responsible paternity, the right of parents to bring up their children and the formulation of population and development plans by the Government in accordance with the principles of respect for sovereignty.

Id.

216. Id. at 149. The country of Malta joined the consensus with the following written reservation: "The interpretation given by Malta is consistent with its national legislation, which considers the termination of pregnancy through induced abortion as illegal." Id.

217. Id. at 140. The delegation of Paraguay made the following oral reservation: In accordance with the introduction to chapter II of the Programme of Action, the delegation of Paraguay would like to express the following reservations.

On chapter VII, paragraph 7.2, the right to life is the inherent right of every human being from conception to natural death. This is stipulated in article 4 of our national Constitution. Therefore, Paraguay accepts all forms of family planning with full respect for life, as provided for in our national Constitution, and as an expression of exercising responsible parenthood.

Id.

218. Id at 142. Argentina introduced the following written reservation into the record of the Conference:

The Argentine Republic accepts Principle 1 on the understanding that life exists from the moment of conception and that from that moment every person, being unique and unreproducible, enjoys the right to life, which is the source of all other individual rights.

Id.

219. Id at 146-49. After significant turmoil, the Holy See joined the consensus document and entered general reservations to chapters VII, VII, XI, XII, XIII, XIV, XV and XVI and the following specific reservation regarding abortion:

But there are other aspects of the final document which the Holy See cannot support. Together with so many people around the world, the Holy See affirms that human life begins at the moment of conception. That life must be defended and protected. The Holy See can therefore never condone abortion or policies which favour [sic] abortion. The final document, as opposed to the earlier documents of the Bucharest and Mexico City Conferences, recognizes abortion as a dimension of population policy and, indeed of primary health care, even though it does stress that abortion should not be promoted as means of family planning and urges nations to find altematives to abortion. The preamble implies that the 
conflicts with their constitutions which protect life from the moment of conception. Honduras, ${ }^{220}$ Nicaragua, ${ }^{221}$ the Dominican Republic, ${ }^{222}$

document does not contain the affirmation of a new internationally recognized right to abortion.

Id.

220. Id. at 137-38. Honduras introduced the following oral reservation:

The delegation of Honduras in supporting the Programme of Action of the International Conference on Population and Development bases itself on the Declaration of the Fifteenth Summit of Central American Presidents, adopted at Guacimo de Limon, Costa Rica, on 20 August 1994 and bases itself specifically on the following:

(a) Article 65 of the Constitution of the Republic of Honduras, which provides for the fact that the right to life is inviolable, and articles 111 and 112 of the same Constitution, which state that the State must protect the institution of the family and marriage and the right of men and women to contract marriages and common law marriages;

As a consequence of this, one accepts the concepts of "family planning", 'sexual health', 'reproductive health', 'matemity without risk', 'regulation of fertility', 'reproductive rights' and 'sexual rights' so long as these terms do not include 'abortion' or 'termination of pregnancy,' because Honduras does not accept these as arbitrary actions; nor do we accept them as a way of controlling fertility or regulating the population.

Id.

221. Id. at 139. Nicaragua orally made this reservation:

The Government of Nicaragua, pursuant to its Constitution and its laws, and as a signatory of the American Convention on Human Rights, confirms that every person has a right to life, this being a fundamental and inalienable right, and that this right begins from the very moment of conception.

....

Second, we accept the concepts of 'family planning,' 'sexual health,' 'rcproductive health,' 'reproductive rights' and sexual rights' expressing an explicit reservation on these terms and any others when they include 'abortion' or 'termination of pregnancy' as a component. Abortion and termination of pregnancy can under no circumstances be regarded as a method of regulating fertility or a means of population control.

....

Fourth, Nicaragua acoepts therapeutic abortion on the grounds of medical necessity under our Constitution. Thus, we express an explicit reservation on 'abortions' and 'termination of pregnancy' in any part of the Programme of Action of this Conference.

Id.

222. Id. at 143. The Dominican Republic set forth its written reservation as follows:

Pursuant to rule 33 of the rules of procedure of the Conference (AVCONF.171/2) the Dominican Republic joins in the general agreement on the Programme of Action. However, in accordance with its Constitution and laws and as a signatory of the American Convention on Human Rights, it fully confirms its belief that everyone has a fundamental and inalienable right to life an that this right to life begins at the moment of conception.

Accordingly, it accepts the content of the terms "reproductive health", "sexual 
Peru ${ }^{223}$ and Guatemala ${ }^{224}$ accepted the concepts of "family planning," "sexual health," "reproductive health," "maternity without risk," "regulation of fertility," "reproductive rights" and "sexual rights" only so long as those terms did not include "abortion" or "termination of pregnancy." Numerous Islamic nations, including Yemen, ${ }^{225}$ the United Arab Emirates ${ }^{226}$ and Libyan Arab

health,' 'safe motherhood,' 'reproductive rights,' 'sexual rights' and 'regulation of fertility' but enters an express reservation on the content of these terms and of other terms when their meaning includes the concept of abortion or interruption of pregnancy.

Id.

223. Id. at 150-51. Peru issued a written reservation concerning abortion:

1. The main lines of the Programme of Action will be implemented in Peru under the Constitution and laws of the Republic and, inter alia, under the international human rights treaties and the Convention on the Rights of the Child, which have been duly approved and ratified by Peru.

2. We must mention in this context article 2 of the Constitution, which accords to everyone the right to life from the moment of conception; abortion is rightly classified as a crime in the Criminal Code of Peru, with the sole exception of therapeutic abortion.

....

4. The Programme of Action contains concepts such as "reproductive health", "reproductive rights" and "fertility regulation", which in the opinion of the Peruvian Government require more precise definition, with the total exclusion of abortion on the ground that it is inconsistent with the right to life.

ld.

224. Id. at 144-45. Guatemala entered the following written, express reservation: We also enter express reservation on:

(a) Chapter II (Principles): we accept this chapter but note that life exists from the moment of conception and that the right to life is the source of all other rights;

(c) Chapter VII: we enter a reservation on the whole chapter, for the General Assembly's mandate to the Conference does not extend to the creation or formulation of rights; this reservation therefore applies to all references in the document to 'reproductive rights,' 'sexual rights,' 'reproductive health,' 'fertility regulation,' 'sexual health,' 'individuals,' 'sexual education and services for minors,' 'abortion in al its forms,' 'distribution of contraceptives' and 'safe motherhood.'

Id.

225. Id. at 141. The representative from Yemen included the following reservation on the record:

In chapter VIII, we have some observations to make, particularly relating to paragraph 8.24. Actually, we wanted to delete the words 'sexual activity.' And, if we cannot delete them, then we wish to express our reservations. In paragraph 8.25 , concerning 'unsafe abortion,' we find that the definition is unclear and is not in accordance with our religious beliefs. In Islamic Sharia there are certain clearcut provisions on abortion and when it should be undertaken. We object to the expression 'unsafe abortion.' We wish to express our reservations on paragraph

Id. 8.35, relating to 'responsible sexual behavior.'

226. Id. at 141. The United Arab Emirates orally introduced this reservation:

The delegation of the United Arab Emirates believes in protecting man and promoting his welfare and in enhancing his role in the family and in the State and 
Jamahiriya ${ }^{227}$ objected to the provision on abortion included in the 1994 Population Report because it contravenes the laws concerning abortion in the Islamic Sharia.

Finally, the 1994 Population Conference opened with an address by the Prime Minister of Pakistan calling for "every child conceived" to be loved. Prime Minister Benazir Bhutto of Pakistan stated, "I dream of a Pakistan, of an Asia, of a world where every pregnancy is planned, and every child conceived is nurtured, loved, educated and supported."228

Plainly, the numerous reservations to the 1994 Population Report concerning abortion and the explicit language of the Report itself indicate that nations do not agree on the existence of an international right to abortion. Although the 179 states attending the 1994 Population Conference reached a consensus on the 1994 Population Report, this consensus did not extend to the existence of an international right to abortion. Because the prior international documents concerning abortion are unclear, the national legislation on abortion is inconsistent and the consensus reached at the 1994 Population Conference did not include agreement on the existence of a right to abortion, the right to abortion is not included within the international customary right to reproductive choice.

\section{B. The Right to Freely Decide the Number and Spacing of Children}

However, the international right to reproductive freedom does include the right to "freely" decide the number and spacing of children. Individuals and couples have a right to be free from government coercion and government incentives and disincentives designed to regulate their level of fertility. The 1994 Population Report emphasizes that the right to reproductive choice includes the "right to make decisions concerning reproduction free of discrimination, coercion and violence"229 and stresses that "[a]ny form of coercion has no part to play" in family planning programs. ${ }^{230}$ Nevertheless, as the 1994 Population Report

at the international level. We consider also that man is the central object and the means for attaining sustainable development. We do not consider abortion as a means of family planning, and we adhere to the principles of Islamic law also in matters of inheritance.

Id.

227. Id. at 139. The representative from Libyan Arab Jamahiriya made the following oral reservation: 'I also want to express a reservation on the words 'unwanted pregnancies' in paragraph 8.25 , because our written Constitution does not allow the State to undertake abortions unless the mother's health is in danger." Id.

228. 1994 Population Report, supra note 1, annex II.

229. 1994 Population Report, supra note 1, at 43, para. 7.3.

230. 1994 Population Report, supra note 1, at 46, para. 7.12. 
recognizes, governments have consistently violated the right to reproductive choice by using coercion and incentives and disincentives. ${ }^{231}$

\section{Government Coercion}

Government coercion occurs where the state denies "informed free choice" through legal and/or policy measures. ${ }^{232}$ Honoring Human Rights defines coercion to include "forced abortion, sterilization, or contraceptive use; the denial of safe abortion; and more subtle activities, such as the imposition of psychological pressure and incentives that compromise voluntary choice." ${ }^{\text {"233 }}$ The most well known example of the use of coercive government policies to regulate fertility is the People's Republic of China's (China's) "One-Child Policy."234

In 1980, China amended its marriage law and created a duty upon families to practice family planning. ${ }^{235}$ This duty was constitutionalized in 1982: "Both husband and wife have the duty to practice family planning." ${ }^{236}$ China introduced its "One-Child Policy" in 1980. The policy outlined the duty of the husband and wife to practice family planning and required that couples have only one child. ${ }^{237}$

At the national level, China officially denies using coercive measures to implement its "One-Child Policy."238 Nevertheless, state and provincial laws and regulations are clearly coercive. In the province of Guangdong,

231. 1994 Population Report, supra note 1, at 46, para. 7.12. "In every society there are many social and economic incentives and disincentives that affect individual decisions about child-bearing and family size. Over the past century, many Governments have experimented with such schemes, including specific incentives and disincentives, in order to lower or raise fertility." ld.

232. Id. at 46 , para. 7.12 .

233. Honoring Human Rights, supra note 4, at 100.

234. For a general discussion of China's policies, see Mark Savage, The Law of Abortion in the Union of Soviet Socialist Republics and the People's Republic of China: Women's Rights in Two Socialist Countries, 40 STAN. L. REV. 1027, 1084-91 (1988) [hereinafter The Law of Abortion in the U.S.S.R. and China]; Honoring Human Rights, supra note 4, at 98-99; and Case Studies in Population Policy: China, U.N. ESCOR, POPULATION POLICY PAPER No. 20, at 40-45, U.N. Doc. ST/ESA/SER.R/88 (1989) [hereinafter China Case Study].

235. Marriage Law of the P.R.C., art. 12 (1980) (adopted on Sept. 10, 1980 by the Third Session of the Fifth National People's Congress), translated in BEIJING REv., at 24 (Mar. 16, 1981) (unofficial translation) in The law of Abortion in the U.S.S.R. and China, supra note 234, at 1084. "Husband and wife are duty bound to practice family planning." Id.

236. Constitution of the People's Republic of China, art. 49, reprinted in 4 CONSTITUTIONS OF THE COUNTRIES OFTHE WORLD; CHINA 46 (Albert P. B laustein \& Gisbert H. Flanz eds., 1992). See also 2 Laws and Regulations of THE PEOPle's Republic of China 15, 23-24 (officia] English translation).

237. The Law of Abortion in the U.S.S.R. and China, supra note 234, at 1084-85.

238. Honoring Human Rights, supra note 4, at 98 . In 1990, China's Family Planning Minister Peng Peiyun was quoted as saying, "In no case is coercion allowed as a means of implementing [the] family planning policy." In 1992, he said, "It is the firm policy of the Chinese government to prohibit coercive action in implementing family planning." Id. 
a woman of child-bearing age who has given birth to one child must take the measure to use an intrauterine device, ... a woman who has given birth to two children must take the sterilization measure, ... [and] a woman who is pregnant beyond the plan must take remedial measures (i.e. abortion) . . . . ${ }^{239}$

In Hebei Province, if a woman who has already had one-child becomes pregnant, she must abort the child, and either she or her husband must undergo sterilization. ${ }^{240}$ In only a five month period in 1983, the province of Hebei performed 300,000 abortions. ${ }^{241}$ Further, a number of provinces use the "double contracting system," which requires couples to enter into contracts promising not to have any more children in exchange for certain financial bonuses and awards. The contract creates a legal obligation enforceable by the judicial system. ${ }^{242}$ Clearly, these provincial policies adopted to implement the national "One-Child Policy" force families to limit their number of children. Ultimately, China's policies violate the right of every couple and individual to freely decide the number and spacing of their children.

India's policies also violate the right to reproductive choice. In the 1970's, India permitted state legislatures to enact laws for compulsory sterilization. ${ }^{243}$ The state of Maharashtra enacted such a law, and police carried out the policy by rounding up millions of people who were sterilized against their will. ${ }^{24}$ Currently, the most egregious abuses have been curtailed, but sterilization camps still exist in some areas. ${ }^{245}$ In Indonesia, soldiers accompany family planning workers on "safaris" into villages, where workers espouse the virtues of family planning and implicitly threaten villagers with punishment if they do not accept the government's form of birth control. Often this results in mass acceptance of these family planning services. ${ }^{246}$

239. The Law of Abortion in the U.S.S.R. and China, supra note 234, at 1089 (citing Guangzhow Guangdong Provincial Service radio broadcast, Apr. 22, 1983 (in Mandarin)), transcribed and translated in Guangdong Holds Family Planning Work Conference, U.S. JONT Publications Res. Serv. China Rep.: Pol. Soc. \& Mr. AFF., May 26, 1983, at 84 (no. 83553).

240. Id. at 1089.

241. Id (citing Shijiazhuang Hebei Provincial Service radio broadcast, June 15, 1983 (in Mandarin)), transcribed and translated in Hebei Family Planning Issues Discussed: Success Noted, U.S. ForEIGN BROADCAST INFO. SERV. DAILY REP.: CHINA, June 27, 1983, at RI (no. 83 124).

242. Id. at 1088-89.

243. Rudolf Andorka, The Use of Direct Incentives and Disincentives and of Indirect Social Economic Measures in Fertility Policy and Human Rights, U.N. ESCOR, Population and Human Rights: Proceedings of the Expert Group Meeting on Population and Human Rights, at 132, 136, U.N. Doc. ST/ESA/SER.R/107 (1989).

244. Honoring Human Rights, supra note 4, at 97-98.

245. Id.

246. Honoring Human Rights, supra note 4, at 99 . Of late, the Indonesian government has supported Norplant as the proper method of birth control. Id 
These overt coercive methods of regulating women's fertility clearly violate the international customary right to reproductive choice. The right includes the right to freely decide the number and spacing of children. The right is foreclosed when governments use the legal process to require contraceptive use. The right to reproductive choice is also violated when governments offer incentives and impose disincentives on the exercise of the right.

\section{Incentives and Disincentives}

Numerous governments throughout the world offer financial incentives and disincentives to individuals and couples to encourage them to have fewer children. In many countries, particularly developing countries, where families are poor, these financial incentives and disincentives remove the choice of whether to bear more children from the individual and couple. Whether to bear more children becomes an economic decision based heavily upon the offer of incentives or the imposition of disincentives.

Financial incentives and disincentives "encourage" families throughout the world to reduce fertility. In China, mothers who have received a "one-child certificate" receive a longer maternity leave with full pay, and children of onechild families receive priority in medical treatment and admission to nurseries and schools. ${ }^{247}$ Furthermore, only those families with one child are eligible for health fee subsidies from the government. ${ }^{248}$ In the Shanxi Province, a family loses twenty percent of its annual income for the birth of a second child and thirty percent of its annual income for a third child. ${ }^{249}$ In 1985, Kenyan leader Daniel Arap Moi warned that families who had more than four children would lose certain social benefits. ${ }^{250}$ South Korea offers housing loan preferences and free medical care for young children to two-child families who have been sterilized. ${ }^{251}$

These financial incentives and disincentives coupled with the economic reality of life in a developing country foreclose an individual and couple's decision of whether to have more children. "For people who are desperately poor, there is no such thing as free choice ... [t]hus in practice incentives often have more to do with coercion than with choice."252 Financial incentives and disincentives remove free choice from individuals and couples and violate their international right to reproductive choice.

247. China Case Study, supra note 234 , at 44.

248. Id.

249. The Law of Abortion in the U.S.S.R. and China, supra note 234 at 1086-87.

250. MOFFETT, supra note 11, at 191.

251. Id.

252. MOFFETT, supra note 11 , at 191-92. 


\section{CONCLuSION}

Currently, the world's population is growing at a rapid rate. In the past twenty years, efforts have reduced the fertility rate throughout the world to just under four children per couple. Nevertheless, replacement level of 2.1 children per couple must be reached to achieve sustainable development.

The limits to growth view asserts that the earth has a certain carrying capacity that may be reached and exceeded if population growth is not curtailed. On the other hand, the revisionist view contends that the scarcity of natural resources will create new technological innovations that will prevent an increase in population from breaching the earth's carrying capacity. Past evidence supports both positions. Nevertheless, current trends indicate a decline in the per capita availability of natural resources.

Although both views have influenced world population policies, the limits to growth position is dominant. Currently, the limits to growth viewpoint advocating sustainable development affects world population policies. Thus, any review of international human rights in population policies necessarily must be completed within the context of the debate over environmental degradation and population.

International and national population policies have developed into an international customary right to reproductive choice. To develop into customary law, a principle must be a general and consistent practice followed by states from a sense of legal obligation. International documents and national legislation evidence customary law.

The right to reproductive choice derives from various international treaties and non-binding resolutions and from the various laws of nations. Over the past thirty years, numerous international documents have recognized the right to reproductive choice. Most recently, 179 nations joined in consensus at the 1994 Population Conference to recognize this right. Furthermore, every country in the world, save seven, through national legislation, supports the right to reproductive choice. With such universal support, the right to reproductive choice has developed into an international customary right.

The scope of the customary right to reproductive choice necessarily encompasses two primary rights: the right to the information, education and means to determine the number and spacing of children and the right to do so freely.

The right to information, education and means to exercise the right to reproductive choice includes the right to information about and access to contraceptives, the right to education, the right to be free from discrimination and violence and the right to reproductive health services. This right does not include the right to abortion. Abortion is not consistently accepted within international documents and is not universally guaranteed in national legislation.

The second right embodied in the right to reproductive choice is the right to decide "freely" the number and spacing of children. This includes the right to 
be free from governmental coercion, including overt coercion, incentives and disincentives, when exercising the right to reproductive choice.

With the adoption of the 1994 Population Report at the 1994 U.N. International Population and Development Conference, the right to reproductive choice has developed into customary international law. As a principle of customary international law, every state in the international arena is bound to respect the human rights of all couples and individuals to decide freely and responsibly the number and spacing of their children and to have the information and means to do so.

Jill M. Bracken

* J.D., May 1995, Indiana University School of Law-Indianapolis. 
